\title{
Decline in Giant Tree Numbers: Status Report for Santa Catarina State and Perspectives for Brazil
}

\author{
Marcelo Callegari Scipioni ${ }^{1}$ (D), Rafael de Paiva Salomão, ${ }^{2,3}$, \\ Alexander Christian Vibrans ${ }^{4}$, Heitor Felippe Uller ${ }^{4}$ \\ ${ }^{1}$ Departamento de Agricultura, Biodiversidade e Florestas, Universidade Federal de Santa Catarina - UFSC, \\ Curitibanos/SC, Brasil \\ ${ }^{2}$ Programa de Pós-graduação em Ciências Biológicas, Universidade Federal Rural da Amazônia - UFRA, Belém/PA, Brasil \\ ${ }^{3}$ Museu Paraense Emílio Goeldi, Belém/PA, Brasil \\ ${ }^{4}$ Departamento de Engenharia Florestal, Universidade Regional de Blumenau - FURB, Blumenau/SC, Brasil
}

\begin{abstract}
Loss of large trees due to indiscriminate timber cutting and opening of new areas for human use is a global problem. Brazil is well known for tree species richness within its extensive forested areas composed of various biomes. Giant trees are "key" to recognize the original forest structure. Decline of their populations in Brazil may be estimated by comparing data of the National Forest Inventory (NFI) with those of regional data and other surveys. In fact, Santa Catarina is the first state in Brazil to have currently completed its forest inventory. However, only few large trees were sampled systematically. Recognition of the maximum tree growth is important for their ecological management and tourism potential. Public policies for cataloging and management of these resources must be developed before it is too late.
\end{abstract}

Keywords: ancient trees, large old trees, tree protection, forest inventory, conservation. 
Populations of large trees, an important element in forests, agricultural areas, and urban environments, are declining throughout the world (Lindenmayer \& Laurance, 2017). Only 50 out of ca. 100,000 estimated tree species worldwide exceed $70 \mathrm{~m}$ in height (Tng et al., 2012). Although only one such tree has been recently recorded for Brazil (Gorgens et al., 2019), it seems that many other trees are likely to exist. They are vulnerable to intentional or accidental destruction and are in danger of extinction. Recognition of their loss has been acknowledged worldwide in the last decade (Crowther et al., 2015; Lindenmayer et al., 2012; Lindenmayer \& Laurance, 2017). Few studies highlight loss of large trees and their density in landscapes dominated by humans (Liu et al., 2019). Despite the recognized ecological significance of large trees within different forest typologies, relatively little is known about their distribution and abundance on the global scale (Lutz et al., 2018).
Gutiérrez (2016) denominates large trees an unrecognized natural heritage of Chile, citing two examples, one of $4.2 \mathrm{~m}$ diameter at breast height ( $\mathrm{dbh}$ ), Nothofagus dombeyi (Mirb.) Oerst., and another one of 3,622-year-old, Fitzroya cupressoides (Molina) I.M. Johnst. The Big Tree Program in the United States of America (USA), begun in 1940, has been recording measurements of largest trees, covering all of its states and listing both native and naturalized species (Van Pelt, 2001). Regrettably, there are only a few records of the size of large individual trees in Brazil, lacking knowledge of their population dynamics and threat of extinction (Scipioni et al., 2019).

Among largest trees in the Brazilian rainforests are imbuia (Ocotea porosa (Nees \& Mart.) Barroso), cedro (Cedrela fissilis Vell.), canafístula (Peltophorum dubium (Spreng.) Taub.), ficus (Ficus spp.), jequitibá (Cariniana legalis (Mart.) Kuntze), kapok (Ceiba pentandra (L.) Gaertn.), among others (Figure 1). Their

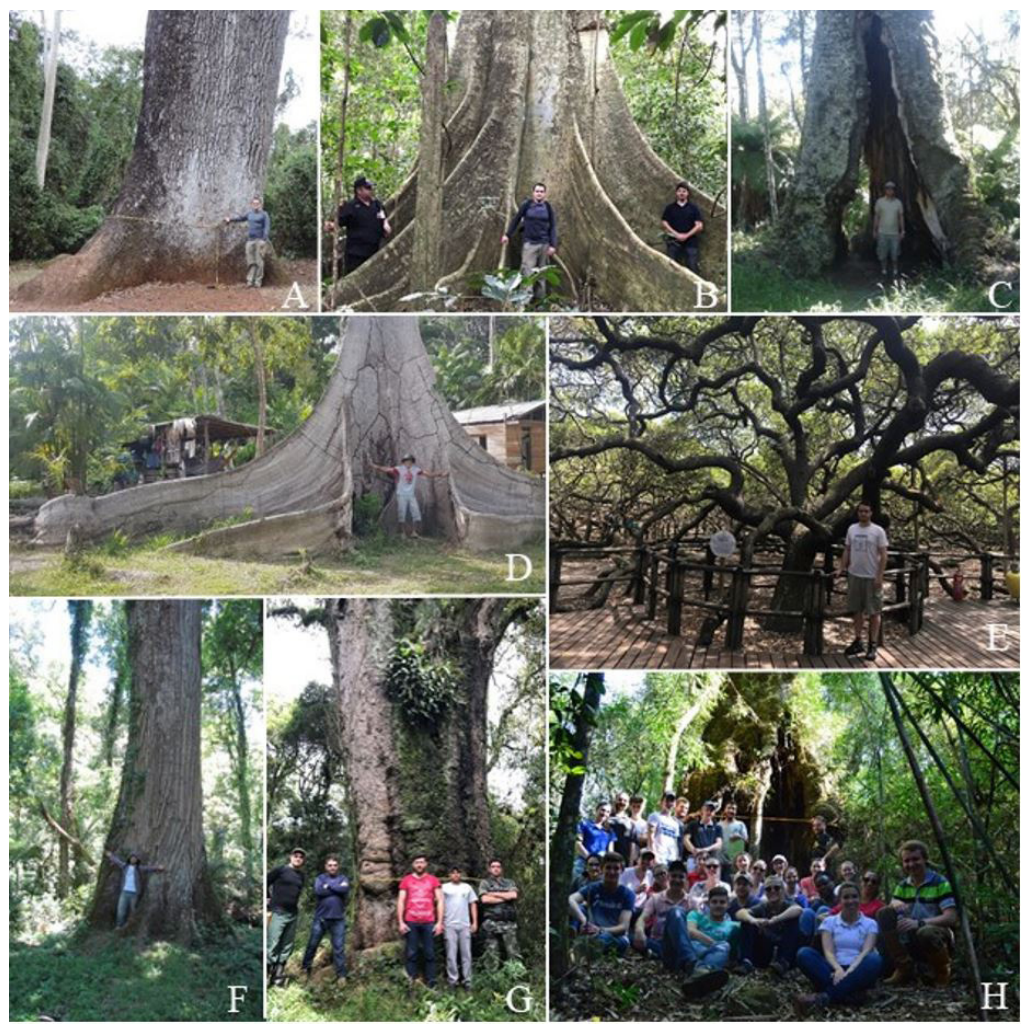

Figure 1. Giant trees in Brazil: (A) jequitibá - Cariniana legalis (Mart.) Kuntze; (B) ficus - Ficus spp., Parque Estadual Vassununga, SP (A-B); (C) pinheiro do Paraná (Paraná pine) - Araucaria angustifolia (Bertol.) Kuntze., São Joaquim, SC; (D) sumaúma (kapok) - Ceiba pentandra L., Ilha de Santana, AP (photo: Gustavo Garcia); (E) cajueiro (Cashew nut tree) - Anacardium occidentale L., Praia de Pirangi, RN; (F) cedro - Cedrela fissilis Vell., Caçador, SC; (G) imbuia - Ocotea porosa (Nees \& Mart.) Barroso, Vargem Bonita, SC; (H) canafístula - Peltophorum dubium (Spreng.) Taub., Parque Estadual Fritz Plaumann, SC (photo: Karine L. dos Santos). 
trunks may exceed $2.5 \mathrm{~m}$ dbh. One Brazilian nut tree (Bertholletia excelsa Bonpl.) has been recorded with $5.25 \mathrm{~m}$ in dbh (Salomão, 1991) and one jequitibá of $4.01 \mathrm{~m} \mathrm{dbh}$ (Figure 1A). Large trees in the rainforest may live longer than 1,400 years (Chambers et al., 1998). There is a lack of records for giant trees in the country, concerning the height parameters of largest trees remaining, and these parameters could be estimated from references found in the studies in the 1970s (Reitz et al., 1978), probably not yet re-assessed using modern techniques and likely no longer exist. On the other hand, a recent discovery of an $88.5 \mathrm{~m}$ tree in the Amazon basin, measured using Light Detection and Ranging (LIDAR) technology (Gorgens et al., 2019), is an exception.

The concept of giant trees is not dependent on their age or size. The definition of a large old tree must be based on its relative size (diameter at breast height and height) and be species-specific. There are fast-growing species reaching large size that are not long-lived. With strong evidence of tree height deterioration and crown failure, the oldest living trees are not necessarily the tallest (Lindenmayer et al., 2012). Other forms of arboreal life, represented by plant colonies, may perpetuate themselves over centuries and millennia. The cashew nut (Anacardium occidentale L.) of the Brazilian Northeast is an example of a giant tree of anomalous growth, with pendent branches rooting in the ground and forming large individuals occupying ca. 7,300 $\mathrm{m}^{2}$ (Figure 1). Having records of such trees and their conservation status is of high importance, both ecologically and economically.

Ocotea porosa is the state symbol tree of Santa Catarina. However, informations on the age and location of its largest trees are missing. On the other hand, it is known for Paraná pine (Araucaria angustifolia) the locations of these giant trees in Brazil, with the largest individual found in Santa Catarina (Scipioni et al., 2019). Both of them represent the most important state species. The Santa Catarina Forest Inventory (in Portuguese - Inventário Florístico Florestal de Santa Catarina (IFFSC)) survey recorded only a few large individuals of them from the secondary forests formed by young trees with thin trunks and low canopy. As reported by Scipioni et al. (2019) for the Araucaria Forest and by Gorgens et al. (2019) for the Amazon Forest, in these areas exist a populational imbalance and also loss of large trees due to the absence of a historical record for the original forests.

Current forest policies in Brazil call for cataloging the remaining forests using standardized methodology. The IFFSC was firstly in the country to complete its sampling (Vibrans et al., 2010), revealing intensively exploited forests. The IFFSC data of 114,836 trees yielded only five giant trees of dbh $>1.5 \mathrm{~m}$, commonly reported from 1950s and 1970s (Reitz et al., 1978; Scipioni et al., 2019). Data of the principal species of giant trees of South and Southeast Brazil, sampled by Scipioni et al. (2019) and Reitz et al. (1978), and of North Brazil by Salomão $(1991,2009)$, are cited in this paper. They could notice the devastating effect of disorderly exploitation of forest resources, poor forest management techniques, and also lack of awareness of the importance of their conservation in Brazil, and the data are presented here in a dbh/height scatter plot (Figure 2). Due to their scarceness, one of the most important Brazilian gymnosperms, Araucaria angustifolia, with few trees of $>2 \mathrm{~m}$ dbh (Scipioni et al., 2019), had no records in state inventories. The biotic, ecological, and economic functions associated with large trees are in danger of being lost in the scenario of an increasing environmental degradation, highlighting the need for undertaking forest inventorization of large trees and of old-growth forests.

New policies and management action to conserve existing large trees are urgently needed. In order to sustain their ecological and economic functional properties, recognition and cataloging of large individual trees and old-growth forests as the first step is called for, apart from management of their populations to ensure their perpetuation as the second step (Gutiérrez, 2016; Lindenmayer et al., 2013; Lutz et al., 2018; Scipioni et al., 2019). Lindenmayer et al. (2013) argue that conservation of existing large trees by restoring their ecologically effective and viable populations requires creation of protected areas on much longer temporal and spatial scales than those currently practiced in the Amazon. Recognition of old-growth forests in fragmented areas, such as the Atlantic Forest (Scipioni et al., 2019) and the Amazon Forest (Gorgens et al. 2019), in official records, including regular information on the forest health and vitality, tree size, tree life cycles, structure, composition, biomass and carbon stock, are important for the forest management in these distinct developmental stages (Feldmann et al., 2018; Keren \& Diaci, 2018; Merschel et al., 2019). 


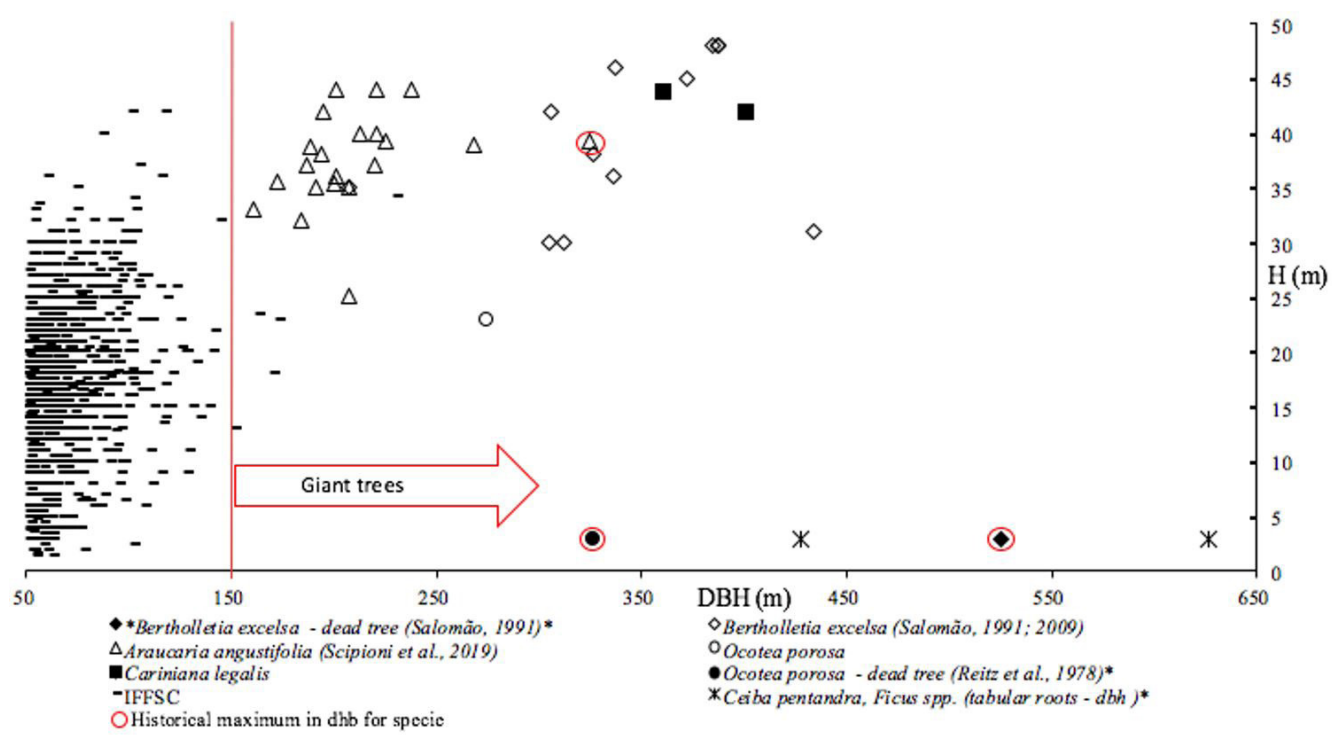

Figure 2. Scatter plot of tree height vs. diameter at breast height $(\mathrm{DBH})$ of the principal giant trees in Brazil. ${ }^{\star}$ In order to visualize the graph, the height of $3 \mathrm{~m}$ was used for trees with no height records.

\section{ACKNOWLEDGEMENTS}

The authors are grateful to the Fundação de Amparo à Pesquisa e Inovação do Estado de Santa Catarina (FAPESC) for the financial support of the Inventário Florístico Florestal de Santa Catarina (IFFSC). The Post-graduate Program for Forestry Engineering at Universidade Federal de Santa Maria (UFSM) and the Conselho Nacional de Desenvolvimento Científico e Tecnológico (CNPq) are acknowledged for funding the post-doctoral research of the first author (proc. 158252/2015-2) and for the ongoing funding of research by Alexander Christian Vibrans (grant \#312075/2013-8).

\section{SUBMISSION STATUS}

Received: 21 apr., 2019

Accepted: 24 sept., 2019

\section{CORRESPONDENCE TO}

\section{Marcelo Callegari Scipioni}

Departamento de Agricultura, Biodiversidade e Florestas, Universidade Federal de Santa Catarina - UFSC, Rod. Ulysses Gabordi, Km 3, s/n, CEP 89520-000, Curitibanos, SC, Brasil e-mail: marcelo.scipioni@gmail.com

\section{FINANCIAL SUPPORT}

Conselho Nacional de Desenvolvimento Científico e Tecnológico (Grant/Award Number: '158252/2015-2', '312075/2013-8'). Fundação de Amparo à Pesquisa e Inovação do Estado de Santa Catarina (Grant/Award Number: 2018TR1021).

\section{REFERENCES}

Chambers JQ, Higuchi N, Schimel JP. Ancient trees in Amazonia. Nature 1998; 391(6663): 135-136. http://dx.doi. org/10.1038/34325.

Crowther TW, Glick HB, Covey KR, Bettigole DS, Maynard DS, Thomas SM et al. Mapping tree density at a global scale. Nature 2015; 525(7568): 201-205. http://dx.doi. org/10.1038/nature14967. PMid:26331545.

Feldmann E, Glatthorn J, Hauck M, Leuschner C. A novel empirical approach for determining the extension of forest development stages in temperate old-growth forests. European Journal of Forest Research 2018; 137(3): 1-15. http://dx.doi.org/10.1007/s10342-018-1105-4.

Gorgens EB, Motta AZ, Assis M, Nunes MH, Jackson $\mathrm{T}$, Coomes $\mathrm{D}$ et al. The giant trees of Amazon basin. Frontiers in Ecology and the Environment 2019; 17(7): 373-374. http://dx.doi.org/10.1002/fee.2085.

Gutiérrez ÁG. Árboles monumentales: un patrimonio natural no reconocido en Chile. Bosque (Valdivia) 2016; 37(3): 445-449. http://dx.doi.org/10.4067/S071792002016000300001 . 
Keren S, Diaci J. Comparing the quantity and structure of deadwood in selection managed and old-growth forests in South-East Europe. Forest 2018; 9(76): 1-16. http:// dx.doi.org/10.3390/f9020076.

Lindenmayer DB, Laurance WF. The ecology, distribution, conservation and management of large old trees. Biological Reviews of the Cambridge Philosophical Society 2017; 92(3): 1434-1458. http://dx.doi.org/10.1111/brv.12290. PMid:27383287.

Lindenmayer DB, Laurance WF, Franklin JF. Global decline in large old trees. Science 2012; 338(6112): 1305-1306. http://dx.doi.org/10.1126/science.1231070. PMid:23224548.

Lindenmayer DB, Laurance WF, Franklin JF, Likens GE, Banks SC, Blanchard W et al. New policies for old trees: averting a global crisis in a keystone ecological structure. Conservation Letters 2013; 7(1): 61-69. http://dx.doi. org/10.1111/conl.12013.

Liu J, Lindenmayer DB, Yang W, Ren Y, Campbell MJ, Wu $\mathrm{C}$ et al. Diversity and density patterns of large old trees in China. The Science of the Total Environment 2019; 655: 255-262. http://dx.doi.org/10.1016/j.scitotenv.2018.11.147. PMid:30471593.

Lutz JA, Furniss TJ, Johnson D, Davies S, Allen D, Alonso A et al. Global importance of large-diameter trees. Global Ecology and Biogeography 2018; 27(7): 849-864. http:// dx.doi.org/10.1111/geb.12747.

Merschel A, Vora RS, Spies T. Conserving dry old-growth forest in Central Oregon, USA. Journal of Forestry 2019; 117(2): 128-135. http://dx.doi.org/10.1093/jofore/fvy085.
Reitz R, Klein RM, Reis A. Projeto Madeira de Santa Catarina. Itajaí: HBR; 1978.

Salomão RP. Estrutura e densidade de Bertholletia excelsa H. \& B. ("castanheira”) nas regiões de Carajás e Marabá, estado do Pará. Boletim do Museu Paraense Emílio Goeldi: Série Botânica. 1991; 7: 47-68.

Salomão RP. Densidade, estrutura e distribuição espacial de castanheira-do-brasil (Bertholletia excelsa H. \& B.) em dois platôs de floresta ombrófila densa na Amazônia setentrional brasileira. Boletim do Museu Paraense Emílio Goeldi: Ciências Naturais 2009; 4(1): 11-25. http://dx.doi. org/10.5123/S1981-81142009000100002.

Scipioni MC, Dobner M Jr, Longhi SJ, Vibrans AC, Schneider PR. The last giant Araucaria trees in southern Brazil. Scientia Agrícola 2019; 76(3): 220-226. http://dx.doi. org/10.1590/1678-992x-2017-0264.

Tng DYP, Williamson GJ, Jordan GJ, Bowman DMJS. Giant eucalypts: globally unique fire-adapted rain-forest trees? The New Phytologist 2012; 196(4): 1001-1014. http://dx.doi.org/10.1111/j.1469-8137.2012.04359.x. PMid:23121314.

Van Pelt R. Forest giants of the Pacific coast. Seattle: University of Washington Press; 2001.

Vibrans AC, Sevgnani L, Lingner DV, Gasper AL, Sabbagh S. Inventário florístico florestal de Santa Catarina (IFFSC): aspectos metodológicos e operacionais. Pesquisa Florestal Brasileira 2010; 30(64): 291-302. http://dx.doi. org/10.4336/2010.pfb.30.64.291. 